\title{
Serum Lipid Profile in Adult Nephrotic Syndrome Patients
}

\author{
Taniza Rahman ${ }^{1}$, Nasima Sultana ${ }^{2}$, Golam Morshed Molla ${ }^{3}$, Pinke Mazumder ${ }^{4}$, \\ Sanjeela Nahreen Chowdhury ${ }^{5}$, Irin Rahman ${ }^{6}$
}

\begin{abstract}
Background: The nephrotic syndrome is a constellation of abnormalities that includes massive proteinuria, hypoalbuminaemia and oedema. Lipid abnormalities have an important biochemical basis in the disease process of adult nephrotic syndrome. Dyslipidaemia in nephrotic syndrome is involved in cardiovascular risk and also accelerates the progression of glomerular dysfunction. Objective: To find out the association between serum lipid profile and nephrotic syndrome in adult. Materials and method: This case control study was carried out in the Department of Biochemistry, Dhaka Medical College, Dhaka, Bangladesh, during the period of July 2013 to June 2014 to evaluate the association of serum lipid profile in adult patients with nephrotic syndrome. One hundred (100) study subjects were included, among them fifty (50) were diagnosed adult nephrotic syndrome patients selected as case and fifty (50) were age and sex matched healthy adult individuals selected as control. Serum lipid profile and serum albumin were measured for both case and control. All the statistical analyses were done by using SPSS for Windows version 20.0. Results: Mean \pm SD of serum total cholesterol (Tchol), triacylglycerol (TAG), high density lipoprotein (HDL-C), and low density lipoprotein ( $L D L-C$ ) of case were $288.23 \pm 35.67 \mathrm{mg} / \mathrm{dL}, 174.53 \pm 18.86 \mathrm{mg} / \mathrm{dL}$, $23.71 \pm 4.58 \mathrm{mg} / \mathrm{dL}$, and $231.16 \pm 34.28 \mathrm{mg} / \mathrm{dL}$ respectively and that of control were $171.04 \pm 24.36 \mathrm{mg} / \mathrm{dL}, 129.58 \pm 23.47 \mathrm{mg} / \mathrm{dL}, 37.5 \pm 7.01 \mathrm{mg} / \mathrm{dL}$, and $103.58 \pm 36.83$ $\mathrm{mg} / \mathrm{dL}$ respectively. Serum Tchol, TAG, LDL-C levels were significantly higher in cases than the control $(p<0.0001)$ and serum HDL-C level was significantly lower in cases than the control $(p<0.0001)$. Conclusion: Dyslipidaemia is associated with adult nephrotic syndrome. Routine check-up of lipid profile will help to prevent the development of cardiovascular and cerebrovascular complications in adult nephrotic syndrome patients.
\end{abstract}

Keywords: Dyslipidaemia; nephrotic syndrome.

$$
\text { Delta Med Col J. Jul 2018;6(2): } 78-81
$$

\section{Introduction}

Nephrotic syndrome is a clinical entity with multiple causes characterized by increased glomerular permeability and manifested by massive proteinuria. ${ }^{1}$ Nephrotic syndrome is

1. Assistant Professor, Dept. of Biochemistry, Ashiyan Medical College, Dhaka, Bangladesh.

2. Professor and Head, Dept.of Biochemistry, Dhaka Medical College, Dhaka, Bangladesh.

3. Professor and Head, Dept.of Biochemistry, Ashiyan Medical College, Dhaka, Bangladesh.

4. Assistant professor, Dept.of Biochemistry, Army Medical College, Bogra, Bangladesh.

5. Assistant professor, Dept.of Biochemistry, Universal Medical College, Dhaka, Bangladesh.

6. Assistant professor, Dept. of Microbiology, Ashiyan Medical College, Dhaka, Bangladesh.

Correspondence: Dr. Taniza Rahman. e-mail: tanizarh@yahoo.com 
represented as urine total protein excretion more than $3.5 \mathrm{gm} /$ day, low serum albumin level $(<2.5$ $\mathrm{gm} / \mathrm{dL}$ ) and peripheral oedema. ${ }^{2}$ The incidence of nephrotic syndrome is $90-100 /$ million in the Indian subcontinent including Bangladesh. ${ }^{3}$ Nephrotic syndrome can affect any age, although it is found with a ratio of adults to children of 26:1. ${ }^{4}$ Nephrotic syndrome is a chronic relapsing disease. Relapse is also higher in children of Bangladesh which is $36.4 \%$. This frequent or infrequent relapse in the nephrotic syndrome may continue even in adult age. ${ }^{5}$ Lipid abnormalities is an important biochemical feature in nephrotic syndrome. Although pathophysiological aspects of this lipid abnormalities have not been completely identified, hypoalbuminaemia, increased lipoprotein synthesis and decreased lipoprotein lipase activity are described as the important causal factor. ${ }^{6}$ In nephrotic syndrome, generally, when oedema regresses, lipid abnormalities tend to being normal but in some cases it may continue after the oedema has disappeared. However it may persist in some cases, leading to increased risk of atherosclerosis in later life. ${ }^{7}$ The magnitude of the most pronounced secondary changes in lipoprotein metabolism in nephrotic syndrome patients correlates with the severity of the syndrome. ${ }^{8}$ Elevation of serum lipid concentrations is an independent risk factor for coronary artery disease and cerebrovascular disease. Concurrent elevation of lipid profile increases these risks. ${ }^{9}$ In nephrotic syndrome, one of the main causes of death is cardiovascular along with chronicity of the syndrome. ${ }^{10}$

Dyslipidaemia in nephrotic syndrome is not only involved in the cardiovascular risk but also accelerates the progression of glomerular dysfunction. ${ }^{11}$ Glomerular disease is a common cause of end stage renal disease (ESRD) and comprises $25-45 \%$ cases of ESRD in developing nations including Bangladesh. ${ }^{12}$ These formidable enemies of health are joining forces to impose a double burden of disease. Limited published data has yet been found regarding this content, though several studies have been done in abroad to establish the relationship between serum lipid profile and nephrotic syndrome. So the present study was designed in a small group of Bangladeshi population to evaluate biochemical parameters in serum lipid profile related with adult nephrotic syndrome.

\section{Materials and method}

This observational case control study was carried out in the Department of Biochemistry, Dhaka Medical College, Dhaka, Bangladesh, from July 2013 to June 2014 to evaluate the association of dyslipidaemia among the adult patients with nephrotic syndrome. For this purpose hundred (100) adult persons enrolled as study subjects. Among them fifty (50) diagnosed nephrotic syndrome patients represented as case and fifty (50) age and sex matched healthy adult individuals represented as control. Cases were selected from diagnosed and admitted patients in department of Nephrology of Dhaka Medical College Hospital on the basis of inclusion and exclusion criteria. Along with the baseline information, $3 \mathrm{ml}$ of fasting (at least 12 hours devoid of meal) blood sample were collected from all study subjects and analyzed for total cholesterol (Tchol), triacylglycerol (TAG), high density lipoprotein (HDL-C) by semiautomated biochemical analyzer. Low density lipoprotein (LDL-C) was calculated by Friedwald equation. ${ }^{13}$

All statistical analyses were done by using the SPSS version 20.0 for Windows. All data were processed to compute mean and standard deviation and expressed as mean \pm SD. Differences of mean among two groups were compared with unpaired Student's t-test. Categorical variables were analyzed by Chi-square test. The significance test was done at $95 \%$ confidence level. 


\section{Results}

The mean $\pm \mathrm{SD}$ age of case and control were $34.62 \pm 6.45$ years and $37.82 \pm 6.93$ years respectively. No statistical significant difference was found regarding age of the case and control groups ( $\mathrm{p}>0.05)$ (Table I).

Table I: Distribution and comparison of age (years) between case and control $(\mathrm{N}=100)$

\begin{tabular}{lcc}
\hline Study subjects & $\begin{array}{c}\text { Age in years } \\
\text { Mean } \pm \text { SD }\end{array}$ & p value \\
\hline Case $(\mathbf{n}=\mathbf{5 0})$ & $34.62 \pm 6.45$ & 0.0626 \\
Control(n=50) & $37.82 \pm 6.93$ & \\
\hline
\end{tabular}

Mean \pm SD of serum total cholesterol (Tchol), TAG, HDL-C, LDL-C of case and control were $288.23 \pm 35.67 \mathrm{mg} / \mathrm{dL}, \quad 174.53 \pm 18.86 \mathrm{mg} / \mathrm{dL}$, $23.71 \pm 4.58 \mathrm{mg} / \mathrm{dL}, 231.16 \pm 34.28 \mathrm{mg} / \mathrm{dL}$ and $171.04 \pm 24.36 \mathrm{mg} / \mathrm{dL}, \quad 129.58 \pm 23.47 \mathrm{mg} / \mathrm{dL}$, $37.5 \pm 7.01 \mathrm{mg} / \mathrm{dL}, \quad 103.58 \pm 36.83 \mathrm{mg} / \mathrm{dL}$ respectively. Serum Tchol, TAG, LDL-C levels were significantly higher in cases than the control $(\mathrm{p}<0.0001)$ but serum HDL-C level was significantly lower in cases than the control $(p<0.0001)$ (Table II, Fig 1)

Table II. Distribution and comparison of serum lipid profile in case and control $(\mathrm{N}=100)$

\begin{tabular}{lccc}
\hline $\begin{array}{l}\text { Parameters } \\
(\mathbf{m g} / \mathbf{d L})\end{array}$ & Case $(\mathbf{n}=\mathbf{5 0})$ & Control $(\mathbf{n}=\mathbf{5 0 )}$ & p value \\
\hline Tchol & $288.23 \pm 35.67$ & $171.04 \pm 24.36$ & $<0.0001$ \\
TAG & $174.53 \pm 18.86$ & $129.58 \pm 23.47$ & $<0.0001$ \\
HDL-C & $23.71 \pm 4.58$ & $37.5 \pm 7.01$ & $<0.0001$ \\
LDL-C & $231.16 \pm 34.28$ & $103.58 \pm 36.83$ & $<0.0001$ \\
\hline
\end{tabular}

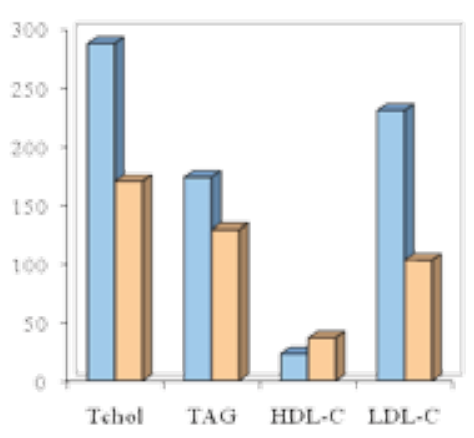

Fig 1: Comparison of Serum lipid profile in case and control

\section{Discussion}

This case control study was designed to observe various changes of biochemical parameters of lipid profile in adult nephrotic syndrome patients comparing to healthy adults. In nephrotic syndrome, hypoproteinaemia stimulates protein synthesis in the liver, resulting in the over production of lipoproteins. On the other hand lipid catabolism is decreased due to lower levels of lipoprotein lipase, the main enzyme involved in lipoprotein breakdown. These two pathophysiological phenomenon are involved in dyslipidaemia in adult patients with nephrotic syndrome. ${ }^{6}$

The result of this study showed that the components of serum lipid profile in case and control had highly significant difference. The mean \pm SD of serum total cholesterol of case was $288.23 \pm 35.67 \mathrm{mg} / \mathrm{dL}$ and that of control was $171.04 \pm 24.36 \mathrm{mg} / \mathrm{dL}$ respectively. Serum total cholesterol level was significantly higher in cases than the control $(p<0.0001)$. This finding was consistent with the finding reported by Adekoya et al. ${ }^{14}$

The mean \pm SD of TAG in cases and control were $174.53 \pm 18.86 \mathrm{mg} / \mathrm{dL}$ and $129.58 \pm 23.47 \mathrm{mg} / \mathrm{dL}$ respectively. The serum TAG level was significantly higher in cases than in control $(\mathrm{p}$ $<0.0001)$. It may be due to increased synthesis of VLDL in liver and decreased lipoprotein lipase and hepatic triacylglycerol lipase activity in nephrotic syndrome. ${ }^{15}$ The mean \pm SD of serum LDL-C in case and control were $231.16 \pm 34.28$ $\mathrm{mg} / \mathrm{dL}$ and $103.58 \pm 36.83 \mathrm{mg} / \mathrm{dL}$ respectively. The serum LDL-C was significantly higher in cases than the control $(p<0.0001)$. This finding was also consistent with the finding reported by Adekoya et al. ${ }^{14}$ and Nandedkar et al. ${ }^{16}$ The mean \pm SD of serum HDL-C level in case and control were $23.71 \pm 4.58 \mathrm{mg} / \mathrm{dL}$ and $37.5 \pm 7.01 \mathrm{mg} / \mathrm{dL}$ 
respectively. The serum HDL-C level was significantly lower in cases than the control $(p<0.0001)$. This finding was similar to the result of a study performed by Penget al. ${ }^{17}$ Two other studies performed in India were found to report similar findings. The study done by Sanjay et al. ${ }^{18}$ at Goalior reported 54 cases having mean \pm SD 24 hour urinary total protein $5.4 \pm 1.3 \mathrm{gm} /$ day, their mean \pm SD serum total cholesterol level was $268.3 \pm 173.3 \mathrm{mg} / \mathrm{dL}$. A cross sectional study performrd by Pandey and Prasad ${ }^{19}$ at Patna among 50 cases of adult nephrotic syndrome patients showed markedly increased mean $\pm \mathrm{SD}$ of serum total cholesterol $(410 \pm 120 \mathrm{mg} / \mathrm{dL}), \mathrm{LDL}(190 \pm 40$ $\mathrm{mg} / \mathrm{dL})$, and TAG (178 $\pm 20 \mathrm{mg} / \mathrm{dL})$ level.

From the result of this study, it can be concluded that dyslipidaemia is associated with nephrotic syndrome in adult. Dyslipidaemia is a well-established risk factor for cardiovascular and cerebrovascular diseases. Therefore adult nephrotic syndrome patients should undergo regular screening with lipid profile for the early detection of dyslipidaemia and should be treated accordingly to prevent associated complications and better management of patients.

\section{References}

1. Adu EM. Serum Lipid Profile Abnormalities among Patients with Nephrotic Syndrome. Int J Med Biomed Res. 2013;2:13-17.

2. Hull RP, Goldsmith DJ. Nephrotic Syndrome in Adults. BMJ. 2008;336:1185-89.

3. Shrivastava RN, Bagga A. Nephrotic Syndrome: Paediatric Nephrology. 4th ed. New Delhi: Jaypee Brothers; 2005.p.161-200.

4. Ramirez JB, Orlando MG, editors. Nefrolgia: Fundamentos de Medicina. Spain: Corporacion Para Investigaciones Biologicas; 2003.p.340.

5. Rahman H, Hossain A, Hossain SZ, Haque AK, Hossain MM, Islam MN. Clinical Profile and Therapeutic Outcome of Nephrotic Syndrome. Journal of Teacher's Association. 1996;7:13.
6. Chan CM. Hyperlipidaemia in Chronic Kidney Disease with Nephrotic Syndrome. Ann Acad Med Singapore. 2005;35:31-35.

7. Thomas ME, Rosenblum AH, Fisher R. Relationship between Blood Lipid and Blood Protein Levels in Nephrotic Syndrome. Am J Dis. 1999;81:207-11.

8. Moulin P, Gerald B, Appel G, Henry N. Increased Concentration of Plasma Cholesteryl Ester Transfer Protein in Nephrotic Syndrome: Role in Dyslipidaemia. Kidney Int. 1992;33:1817-22.

9. Marsh JB. Lipoprotein Metabolism in Experimental Nephrosis. Proc Soc Exp Biol Med. 1996;213:178-86.

10. Lacquaniti A, Bolignano D, Donato V. Alterations of Lipid Metabolism in Chronic Nephropathies; Mechanisms, Diagnosis and Treatment. Kidney Blood Press Res. 2010;33(2):100-10.

11. Vaziri ND. Dyslipidaemia of Chronic Renal Failure: The Nature, Mechanism and Potential Consequences. Am J Renal Physiol. 2006;290:262-72.

12. Rashid HU. Nephrotic Syndrome - Evidence Based Management. Bangladesh Renal J. 2003;22:1-4.

13. Friedwald WT, Levy RI, Frederickson DS. Estimation of the Concentration of Low-Density Lipoprotein Cholesterol in Plasma, Without Use of Preparation Ultracentrifuge. Clin Chem. 1972;18:499-502.

14. Adekoya AO, Adekoya BJ, Desalu OO, Aderibigbe A. A Pattern of Lipid Profile in Adult Nephrotic Syndrome Patients in Nigeria. Int J Bio Med Res. 2011;2:954-60.

15. Arnadottir M. Pathogenesis of Dyslipoproteinemia in Renal Insufficiency: The Role of Lipoprotein Lipase and Hepatic Lipase. Scand J Clin Lab Invest. 1997;57:1-11.

16. Nandedkar PD, Kamble MT, Suryabhan L. Analysis of Lipid Profile and 24 Hour Urinary Protein Excretion as a Predictor of Cardiovascular Risk in CKD with Nephrotic Syndrome. J Pharm Biomed Sci. 2012;21(2):63-71.

17. Peng $\mathrm{H}$, Wang J, Bo H. Dyslipidaemia Acts as a Close Link between Cardiovascular Risk and Renal Progression in Nephrotic Patients. Asian Biomedicine. 2012;6(2):151-57.

18. Dhawale S, Jayant SS, Gaharwar R. Study of Etiological Profile of Nephrotic Syndrome in Adults. Int Journal of Applied Research. 2015;1(9):545-49.

19. Pandey JC, Prasad CK. Lipid Profile Abnormalities in Nephrotic Syndrome. Asian Journal of Biomedical and Pharmaceutical Sciences. 2016;6(54):17-19. 